PR

41,3

260

\section{Is there fire? Executive compensation and employee attitudes}

\author{
Elizabeth T. Welsh
}

Department of Management, University of St Thomas, St Paul, Minnesota, USA

Deshani B. Ganegoda

Department of Management, University of Central Florida, Orlando, Florida, USA

Richard D. Arvey

Department of Management and Organization, National University of Singapore, Singapore

Jack W. Wiley

High Performance Institute, Kenexa, Minneapolis, Minnesota, USA, and

John W. Budd

Department of Work and Organizations, University of Minnesota, Minneapolis, Minnesota, USA

\begin{abstract}
Purpose - This paper aims to examine the relationship between CEO compensation and employee attitudes.

Design/methodology/approach - Based upon equity/organizational justice theories and the CEO compensation literature, hypotheses were developed which suggest that executive compensation and employee attitudes will be related. These hypotheses were tested by linking a large-scale survey of employee attitudes to CEO compensation data for public companies based in the USA.

Findings - Employee attitudes appear to be related to some measures of CEO compensation, although sometimes the relationship that was found was negative and sometimes it was positive, but in all cases the effect size was quite small. Specifically, change in CEO salary was negatively related to evaluation of senior management and general satisfaction. However, change in total CEO compensation was positively related to evaluation of senior management and general satisfaction, while CEO bonus level was positively related to general satisfaction.
\end{abstract}

Research limitations/implications - Limitations of this study include the inability to show a causal relationship, limited external validity, equations that explain only a small amount of variance and attitudinal measures that are single source. Future research which helps understand what employees know and why differences across organizations exist would be helpful.

Practical implications - From an employee attitude perspective, changing performance-based components of CEO compensation (e.g. bonus) is better than changing CEO salary. However, if salary is going to be increased, a communication plan for employees should be developed.

Originality/value - Whether executive compensation has an impact on employees' attitudes has not been explored previously.

Personnel Review

Vol, 41 No. 3, 2012

pp. $260-282$

(C) Emerald Group Publishing Limited 0048-3486

DOI $10.1108 / 00483481211212742$
Keywords Employees attitudes,
Paper type Research paper 
Many words have been used in the popular press and academic literature to describe executive compensation in the USA, including "shameful" (Stolberg et al., 2009), "soaring” (Maremont, 2005), “exorbitant” (Associated Press, 2005), “excess” (Kidder and Buchholtz, 2002), and "extraordinary" (Andersson and Bateman, 1997) - none of them positive. These reactions are driven by the growth of executive compensation over the past two decades. A study by Bebchuk and Grinstein (2005) found that S\&P 500 Chief Executive Officer (CEO) compensation increased on average 146 percent from 1993 to 2003, while senior management compensation - compensation for the next four most senior executives - increased 125 percent over the same time period. In addition, the ratio of total executive compensation to total corporate earnings of their firms increased from 4.8 percent in the years 1993-1995 to 10.3 percent in 2001-2003.

While significant effort has been expended to understand what drives executive compensation and particularly CEO compensation (Devers et al., 2007)[1], there has been much less research on the consequences of executive compensation, especially with respect to employees' attitudes and reactions. It is possible that employees working in firms where top executives make large amounts of compensation relative to other similarly situated executives might respond with negative attitudes toward the organization, management, and other focal targets, but little work has analyzed this important possibility. One study by Andersson and Bateman (1997) examined whether CEO compensation had an impact on employee cynicism using a scenario-based experiment with 207 workers in 68 organizations. The compensation of a fictitious CEO was manipulated along three dimensions:

(1) pay relative to other CEOs in the industry;

(2) pay relative to the average manufacturing worker at the company; and

(3) whether the CEO was on a "lowest paid" or "highest paid" CEO list.

Employees responded to these different vignettes by indicating their degree of cynicism. A relationship was found between relative CEO pay and cynicism, which provides some understanding of whether executive compensation can impact employees' attitudes. However, employees were responding to pencil and paper vignettes rather than "real" executives - actual compensation levels of the executives were not given and relative CEO pay was made salient.

While little empirical work has been completed on this subject, a number of "real world" incidents suggest that there might be a link between executive compensation and employee attitudes, at least under specific conditions. For example, Denver transit workers went on strike partially because management had received raises of between 38 percent and 48 percent while union worker salaries had been frozen (Nguyen, 2006). Similarly, the CEO of American Airlines was forced to resign after it became known that retention bonuses and pension protections were given to managers just after substantial pay concessions had been obtained from unions (Zellner, 2003).

However, it is unclear whether average employees know or care about how much money their executives earn. Given all of the more proximal antecedents of job attitudes (see Humphrey et al., 2007) and the relative difficulty of obtaining pay information, it may be that only in extreme situations, like those above, that relative executive compensation affects the attitudes of employees. Therefore the purpose of this study is to explore the extent to which employee attitudes in the existing US workforce are impacted by executive compensation levels, specifically CEO 
PR

41,3

262

compensation levels. Note carefully that this study is not designed to examine whether executive compensation can affect employee attitudes - anecdotal evidence shows that this is clearly the case under certain circumstances. Nor is this study able to manipulate levels and awareness of executive pay to analyze whether individuals react to CEO compensation in principle. Rather, we examine whether the current state of attitudes of employees in the US workforce are associated with existing compensation levels of executives. In short, given all the smoke that is out there about high levels of CEO compensation in the USA, is there any fire in the workforce?

\section{Hypothesis development}

What is interesting about the question of whether CEO compensation affects employee attitudes[2] is that theory could be used to predict either a negative relationship between attitudes and CEO compensation or a positive one. While there are many theories that might be considered, organizational justice theories and specifically equity theory will be the focus of this examination because of their attention to the distribution of outputs in relationship to inputs and the implications of comparisons that individuals make. We will augment the organization justice/equity theories with current views of $\mathrm{CEO}$ compensation from the compensation literature to develop hypotheses.

We begin with a discussion of equity theory, followed by a discussion of potential drivers of CEO compensation, and then we suggest hypotheses.

\section{Equity theory}

Organizational justice theories, wherein social comparison mechanisms are posited to predict whether individuals perceive their employment world as relatively "just" or "unjust", lend support to the idea that CEO compensation might affect employee attitudes. Starting initially with Adams's well known equity theory (Adams, 1963, 1965), it is proposed that individuals form perceptions and beliefs about the relative nature of their inputs and outcomes compared to other referent sources in an organization. Individuals who perceive their input to outcome ratio to be small when compared to others develop feelings of inequity or injustice and are motivated to reduce this state of inequity. In contrast, when the ratios are in balance, they are relatively satisfied with the situation.

Research has confirmed that individuals in various states of "under-reward" inequity exhibit lower levels of pay and job satisfaction (Oldham et al., 1986), higher levels of absenteeism (Dittrich and Carrell, 1979) and turnover (Telly et al., 1971), lower performance levels (Pritchard et al., 1972) and more deviant behaviors such as theft (Greenberg, 1990). In addition, a meta-analysis conducted by Cohen-Charash and Spector (2001) showed a weighted mean $r$ of 0.47 between perceptions of distributive justice (that are typically based on equity judgments) and job satisfaction based on 23 studies and over 26,000 subjects. Likewise, a weighted mean $r$ of 0.62 was observed for the relationship between justice perceptions and pay satisfaction based on 11 studies and 2,970 subjects, and a weighted mean $r$ of 0.27 for justice perceptions and satisfaction with management based on nine studies and 3,125 subjects. An independent meta-analysis conducted by Colquitt et al. (2001) found similar relationships between distributive justice and a variety of outcomes such as job satisfaction, organizational commitment, performance, trust and withdrawal. 
Initial theories of social comparison emphasized that individuals prefer to select referents who are similar to themselves when making comparisons (e.g. Adams, 1963, 1965; Festinger, 1954). However, subsequent empirical research has revealed that individuals sometimes select referents who are dissimilar to themselves (e.g. Martin, 1981; Mettee and Smith, 1977; Reckman and Goethals, 1973). For example, Goodman $(1974,1977)$ and Rosen (1986) expanded the set of social comparisons by suggesting that equity perceptions could be based on a variety of referents, including others inside or outside of an individual's organization. In addition, Clark and Senik (2009) found that individuals used a variety of referents when they compared their income to others including work colleagues, family, and friends.

Three of the key determinants of referent choice are the availability and salience of information and relevance of the referent (Kulik and Ambrose, 1992). As media attention has increasingly focused on executive compensation, the information on CEO compensation has become more available. In addition, as the difference between executive compensation and average worker compensation has grown, CEO compensation may have become more salient to employees. In terms of relevance, relative deprivation theory (Crosby, 1979, 1984; Runciman, 1966) suggests that individuals go beyond similar others when making comparisons. Specifically, individuals compare their or their group's outcomes to higher-status individuals and groups. These comparisons can lead individuals to experience feelings of deprivation if they perceive that they or their groups are rewarded less favorably than the comparison group (Martin, 1981). Therefore, employees might make equity-based comparisons with executives and CEOs despite the dissimilarity of their positions In fact, Wade et al. (2006) found that lower-level managers did appear to sue the CEO as a referent.

Given this, equity theory would suggest a negative relationship between CEO compensation and employee attitudes if employees believe that CEOs' outputs have grown more quickly than their inputs, but would suggest a positive relationship if employees believe that CEOs' outputs have grown in relationship to their inputs, assuming an initial state of balance between CEO and employee output to input ratios. Interestingly, these contrasting attributions mirror the current literature on CEO compensation (Frydman and Jenter, 2010), where there are divergent views about the determinants of CEO compensation.

\section{Divergent views of CEO compensation}

In a recent qualitative review of the CEO compensation literature, Frydman and Jenter (2010) suggest that there are two primary opposing views of CEO compensation. The first view asserts that CEOs make more than they deserve. They make more than they deserve because they extract rents ("rent extraction view") from the organization by using their power to manipulate the compensation process (Bebchuk and Fried, 2004). In contrast, the second view asserts that CEOs are generally paid efficiently based upon the market for CEO talent and their worth to the companies they lead (see Edmans and Gabaix, 2009). While both views have received some empirical support, neither is completely consistent with all of the historical data.

According to the rent extraction view, CEOs have significant power over key parts of the compensation process and they use this power to increase their pay (Bebchuk and Fried, 2004). Specifically, CEOs have many sources of power including choosing the composition of the board of directors and the rewards that directors earn (Bebchuk

\section{Executive compensation}

263 
PR

41,3

264 and Fried, 2004). Recent backdating scandals, where options were found to be dated based upon maximizing the payout for executives rather than the actual date awarded (see Yermack, 1997; Lie, 2005), show that manipulation does occur in the compensation system. In addition, CEOs have been found to benefit from improved company performance that is not the result of their efforts, but not to suffer when these trends reverse (Bertrand and Mullainathan, 2001; Garvey and Milbourn, 2006). However, this view does not explain the rise in CEO compensation since the 1970s (Frydman and Jenter, 2010). The rent extraction view would suggest that CEO power has increased since the 1970s, given the growth in compensation. However, research has found that corporate governance has got stronger over this time frame, which implies that CEO power has decreased (see Kaplan, 2008).

In contrast, a second view argues that CEO compensation is generally efficient, in that it helps to resolve the principal-agent problem and reflects the market for top executive talent and the performance of the companies they lead (Frydman and Jenter, 2010). Efficiency in this sense means that compensation is related to the CEO's efforts and talent and the return to shareholders and is thus "earned". Empirical work has supported this view. First, Hall and Liebman (1998) showed that due to the number of options and restricted stock that are now routinely part of CEO compensation, their wealth is closely tied to organizational performance. Second, Edmans and Gabaix (2009) found that optimal contracting theories fit with patterns of CEO compensation including the growth in compensation (see also Gabaix and Landier, 2008) and increased use of options. In addition, recent work has found that CEOs provide more value to their organizations than they receive in compensation (Tervio, 2008; Nguyen and Nielsen, 2010). However, this view does not explain compensation trends prior to the 1980s (Frydman and Jenter, 2010), nor does it account for the backdating scandals or the amount of pay that is frequently hidden by corporations (Edmans and Gabaix, 2009).

Extending these views to the employee level, there are at least two different attributions that employees may make when evaluating CEO compensation in their organizations. The rent extraction attribution would attribute CEO compensation to power rather than inputs, while the efficiency attribution would attribute CEO compensation to inputs that the CEO brings to the organization.

\section{Hypotheses}

If lower-level employees attribute the growth in total CEO compensation to rent extraction, equity theory would suggest a negative relationship between total CEO compensation and employee attitudes. In this case, employees would believe that CEOs are receiving outputs that are not related to their inputs (i.e. their performance), and employees would perceive overpayment inequity at higher levels of the organization. These perceptions of distributive injustice would be reflected in employees' evaluations of their own outcomes and attitudes. Based on this, we propose:

H1. Higher levels of total CEO compensation will be negatively related to employee attitudes, including pay and benefits satisfaction, satisfaction with senior management and general satisfaction.

In contrast, if total CEO compensation is believed to be efficient, then equity theory would suggest a positive relationship between CEO compensation and employee attitudes. In this case, because CEOs are receiving outputs based upon their worth and 
performance, employees would perceive an equitable and distributively just workplace which would be reflected in their evaluations. Based on this, we propose:

H2. Higher levels of total CEO compensation will be positively related to employee attitudes, including pay and benefits satisfaction, satisfaction with senior management and general satisfaction.

In addition to looking at total CEO compensation, employees may evaluate distinct components of CEO compensation separately and may make different attributions depending upon which component is being evaluated. One distinguishing characteristic that employees may consider is whether the component is contingent upon performance. For non-performance dependent components, like salary, employees may attribute high levels and large changes to CEO power and ability to control negotiations. This corresponds to the rent extraction view. Thus, employees would believe that CEOs are receiving outputs that are not related to their inputs and would perceive overpayment inequity and distributive injustice for these components. This would be reflected negatively in employees' evaluations of their own outcomes and attitudes. Based on this we propose:

H3. Higher levels of compensation components that are not performance-dependent (e.g. salary) will be negatively related to employee attitudes, including pay and benefits satisfaction, satisfaction with senior management and general satisfaction.

In contrast, other major components of executive compensation are contingent on company performance. For example, stock options are only valuable if the company performs well in the stock market, and the CEO only gets an annual bonus if the company hits its targets. Components of compensation that are performance-based correspond more closely to the view that CEO compensation is efficient, and that CEOs are receiving outputs based upon their inputs. When evaluating these components, employees would perceive a more equitable and distributively just workplace, and this would be reflected positively in their evaluations of their own outcomes and attitudes. Based on this we propose:

H4. Higher levels of compensation components that are performance dependent (e.g. annual bonus) will be positively related to employee attitudes, including pay and benefits satisfaction, satisfaction with senior management and general satisfaction.

\section{Methods}

Data and sample

The data for this study originated from the WorkTrends ${ }^{\mathrm{TM}}$ database, a worker opinion database compiled by Gantz Wiley Research. WorkTrends ${ }^{\mathrm{TM}}$ draws its sample of adult workers from a National Family Opinion panel. A stratified sampling technique based on age, income and geography is used in order to closely replicate the adult worker population of the US Census. The data for this study came from the 2005 survey, which was administered in the fourth quarter of 2004.

For the 2005 survey 10,000 surveys were mailed and of those 6,752 completed surveys were returned for a response rate of 67.5 percent. On average the participants were 46 years old. This sample was 47 percent male and 29 percent hourly workers.

\section{Executive compensation}

265 
PR

41,3

266
One question on the survey asked individuals to identify the "full, formal name of the company for which you work". Using the information provided by this question, we entered the company names into Dun \& Bradstreet's Hoover's database and were able to unambiguously link 1,254 participants to a public company (18.6 percent of participants who completed the survey). Individuals excluded at this point either chose not to provide a company name, worked for a governmental or non-profit agency (e.g. army, United States Postal Service, school district, hospital), worked for a company which was in the midst of a merger or had recently merged (e.g. BancOne), or provided a company name that could not be uniquely linked to a single, public company.

Compensation data were then obtained for the identified companies using Standard \& Poor's Compustat Executive Compensation database. This database includes compensation data (e.g. salary, annual bonus, options) for CEOs and senior executives compiled from the SEC 14A filings of S\&P 500, Mid-Cap 400 and Small-Cap 600 companies. Companies not in these indexes (e.g. AC Moore, Del Monte, Willbros Engineering) and foreign companies (e.g. AXA, BAE Systems, Ericsson) are not part of the database, which reduced the final sample to 985 individuals (79 percent of the individuals at uniquely identified companies).

These 985 individuals came from 428 different companies ranging from companies where one employee completed the survey (e.g. ADC, Harley Davidson, Texas Instruments) to Walmart where 56 individuals worked. On average individuals in the final sample were 45 years old. This sample was 54 percent male and 50 percent hourly workers.

While there are significant differences between the original sample and the final sample in terms of age and gender, these differences are not surprising given that they are samples of two different populations. The original sample represents the adult working population while the final sample represents adults working at US-owned, publicly traded companies. Given that compensation data were only available to employees for these types of companies, the final sample represents workers for whom CEO compensation could potentially impact job attitudes.

\section{Measures}

Dependent variables. An array of dependent variables was examined in order to understand the relative relationship of CEO compensation to employee attitudes. Specifically, evaluation of pay and benefits, evaluation of senior management and general satisfaction were considered as dependent variables.

Evaluation of pay and benefits. To measure evaluation of pay and benefits a two-item scale was used. Items asked respondents, using a five-point scale ranging from very good $(=1)$ to very poor $(=5)$, how they would rate "your total benefits program" and "the amount of pay you get on your job". Items were reverse scored in order to have higher scores correspond to higher evaluations and the two items were summed into a composite score. The coefficient $\alpha$ for this scale was 0.69 , which is not surprising given that companies may substitute benefits for pay or pay for benefits when designing compensation plans for employees.

Evaluation of senior management. To measure evaluation of senior management, a six-item scale was used. Items asked respondents to indicate the level of agreement with a series of statements including "Senior management demonstrates that employees are important to the success of the company", "Senior management has 
clearly communicated our company's values", and "When my company's senior management says something, you can believe it's true" using a five-point scale ranging from strongly agree $(=1)$ to strongly disagree $(=5)$. Items were reverse scored in order to have higher scores correspond to higher evaluations. For this scale one missing value was imputed using the two-way imputation method (Bernaards and Sijtsma, 2000) for 14 individuals. Coefficient $\alpha$ for this scale was 0.92 .

General satisfaction. A six-item scale was used to measure general satisfaction. Four of the items asked respondents to indicate how satisfied or dissatisfied they were with a series of items including "Considering everything, how satisfied are you with your job?" and "Considering everything, how would you rate your overall satisfaction in your company at the present time?" using a five-point scale ranging from very satisfied $(=1)$ to very dissatisfied $(=5)$. Two additional items were used asking the extent to which they agreed or disagreed with the statements "I like the kind of work I do", and "Considering everything, I am satisfied with my company" using a five-point scale ranging from strongly agree $(=1)$ to strongly disagree $(=5)$. Items were reverse scored in order to have higher scores correspond to greater satisfaction. For this scale one missing value was imputed for 13 individuals, and two missing values were imputed for one individual using the two-way imputation method (Bernaards and Sijtsma, 2000). Coefficient $\alpha$ for this scale was 0.90 .

Independent variables. The independent variables for this study consisted of compensation amounts for CEOs. Companies must file compensation information for CEOs in order to comply with SEC regulations, and, thus it is possible for employees to have knowledge concerning the compensation levels for these individuals.

CEO compensation figures for 2003 were obtained from the Compustat database. Given that the survey was distributed in the fourth quarter of 2004, 2003 compensation numbers would have been the most recent figures to which employees had access because SEC filings occur after the close of the financial year (in other words, 2003 numbers are available in 2004).

Both compensation level and percentage increase in compensation were considered in the analyses. Percentage increase ("change") was included because employees may find such figures more cognitively accessible, as raises are easier to compare to the employee's situation (e.g. the employee received a 5 percent increase while the CEO received a 33 percent increase, versus the employee made $\$ 50,000$ this year while the CEO made $\$ 2$ million).

CEO total compensation. Total compensation was calculated by summing salary, incentive pay, other annual compensation (e.g. use of company aircraft, interest on deferred compensation), restricted stock awards, other long-term compensation (e.g. contributions to 401(k) plan, life insurance premiums) and dollar value of options exercised in 2003[3]. A total of 749 individuals had CEO total compensation information because 235 individuals worked for companies where the CEO joined or left during 2003 and one individual worked for a company where the information was not available through Compustat.

CEO salary. CEO salary was obtained from the salary field in the Compustat database. CEO salary is a non-performance dependent component of CEO compensation because it is set at the beginning of the year and does not vary based upon how company performance. A total of 750 individuals had CEO salary information because 235 individuals worked for companies where the CEO joined or left during 2003.

\section{Executive compensation}

267 
PR

41,3

268
CEO annual bonus. CEO annual bonus was calculated by subtracting salary from total current compensation. $\mathrm{CEO}$ annual bonus is a performance dependent component of $\mathrm{CEO}$ compensation because it varies based upon whether agreed upon targets or goals are met during the year. A total of 748 individuals had CEO long-term compensation information because 235 individuals worked for companies where the CEO joined or left during 2003 and two individuals worked for companies where the information was not available through Compustat.

CEO long-term compensation. CEO long-term compensation was computed by subtracting total current compensation from total compensation. Long-term compensation includes the value of exercised options, restricted stock and other long-term compensation. CEO long-term compensation primarily consists of stock and options (Frydman and Jenter, 2010) and so is a performance dependent component of total CEO compensation as the value varies with stock market performance. A total of 749 individuals had CEO long-term compensation information because 235 individuals worked for companies where the CEO joined or left during 2003 and one individual worked for a company where the information was not available through Compustat.

Change in compensation. Changes in both total compensation and compensation components were calculated by taking 2003 amounts minus 2002 amounts over 2002 amounts; 2002 and 2003 amounts were used because these would have been the most recent amounts to which employees had access.

In order to calculate change in compensation, both 2002 and 2003 data had to be available and 2002 levels could not be zero (as dividing by zero gives an undefined answer). Therefore, on top of the compensation sample adjustments, additional adjustments were made for compensation changes. Specifically, a total of 746 individuals had a change in total compensation information because of the 749 individuals with 2003 information, three individuals worked for companies where the CEO joined or left during 2002. A total of 732 individuals had change in salary information because of the 750 individuals with 2003 information, 15 individuals worked for companies where the CEO received no salary in 2002 and three individuals worked for companies where the CEO joined or left during 2002. A total of 641 individuals had change in bonus information because of the 748 individuals with 2003 information, 104 individuals worked for companies where the CEO received no bonus in 2002 and three individuals worked for companies where the CEO joined or left during 2002. Finally, 742 individuals had change in long-term compensation information because of the 749 individuals with 2003 information, four individuals worked for companies where the CEO received no long-term compensation in 2002 and three individuals worked for companies where the CEO joined or left during 2002.

Control variables. Two kinds of controls were used:

(1) company-level; and

(2) individual-level.

Company-level controls included industry (manufacturing, service, other), profitability (ROA), and organization size (assets, sales). Theoretically, these variables could impact both CEO compensation and employee attitudes. Given the challenges of running larger organizations, higher compensation due to human capital requirements (Agarwal, 1981) would be warranted, although employees within these large organizations may be less satisfied because they are less connected. In addition, based 
upon agency theory (Tosi et al., 2000), more profitable organizations should have higher CEO compensation levels because owners should reward agents for pursuing owners' goals of profitability and may be nicer places to work as there are fewer financial strains. Finally, given different dynamics across industries, different executive compensation levels (Gomez-Mejia and Wiseman, 1997) and employee attitudes seem reasonable.

Support for the organizational controls comes from previous literature. For example, Murphy (1999) found that industry was related to level of CEO compensation, while Scandura and Williams (2004) and MacDermid et al. (2001) found that it was related to employee attitudes. Similarly, in a meta-analysis Tosi et al. (2000) found that profitability and organizational size were related to level of CEO compensation while Harter et al. (2002) and Schneider et al. (2003) found that profitability and Dekker et al. (1996), MacDermid et al. (2001) and Zipp (1991) found that organizational size were related to employee attitudes.

SIC codes were used to categorize companies into one of three sectors, manufacturing, service and other. Profitability was controlled for using return on assets (ROA), which is an accepted measure of profitability (see Schneider et al., 2003; Tosi et al., 2000) that compares profitability across companies without also measuring company size (Tosi et al., 2000). Sales and assets were used to control for organizational size.

Individual-level control variables included demographics and job characteristics. Demographic controls were household income, age and gender $(1=$ male, $2=$ female). Job characteristic controls included whether the individual was an hourly $(1=$ hourly, $0=$ salary $)$ or salaried employee and whether they were a manager $(1=$ yes, $0=$ no $)$.

\section{Analytical procedure}

In order to maximize the power of the analysis and external validity of the sample, data were analyzed at the individual level. However, a standard OLS regression would have been inappropriate because the error terms of individuals at the same company would not be independent, violating one of the assumptions of OLS regression, and leading to incorrect specification of the standard errors. In order to address this issue, we used a cluster regression technique in STATA that adjusts the variance and covariance matrices to account for interdependent errors within companies and heterogeneous errors across companies (Rogers, 1993; Soldz, 2008). This methodology has previously been used to analyze data at the individual level while accounting for cluster affects within supervisory-subordinate dyads (Glomb and Welsh, 2005) and within work groups (Glomb and Liao, 2003). Another option would have been to use hierarchical linear modeling to analyze the data. However, this would have limited the dataset to only companies with a relatively large number of respondents leading to lower statistical power and a less representative sample, as smaller companies would not have been included in the final analysis.

\section{Results}

Tables I and II present the means, standard deviations, and correlations for the variables used. It is interesting to note from Tables I and II that the direction of the correlations between CEO compensation and employee attitudes varies, sometimes being positively related and sometimes negatively related. Also interesting to note is

\section{Executive compensation}

269 
PR
41,3

270

Table I.

Means, standard deviations and correlations

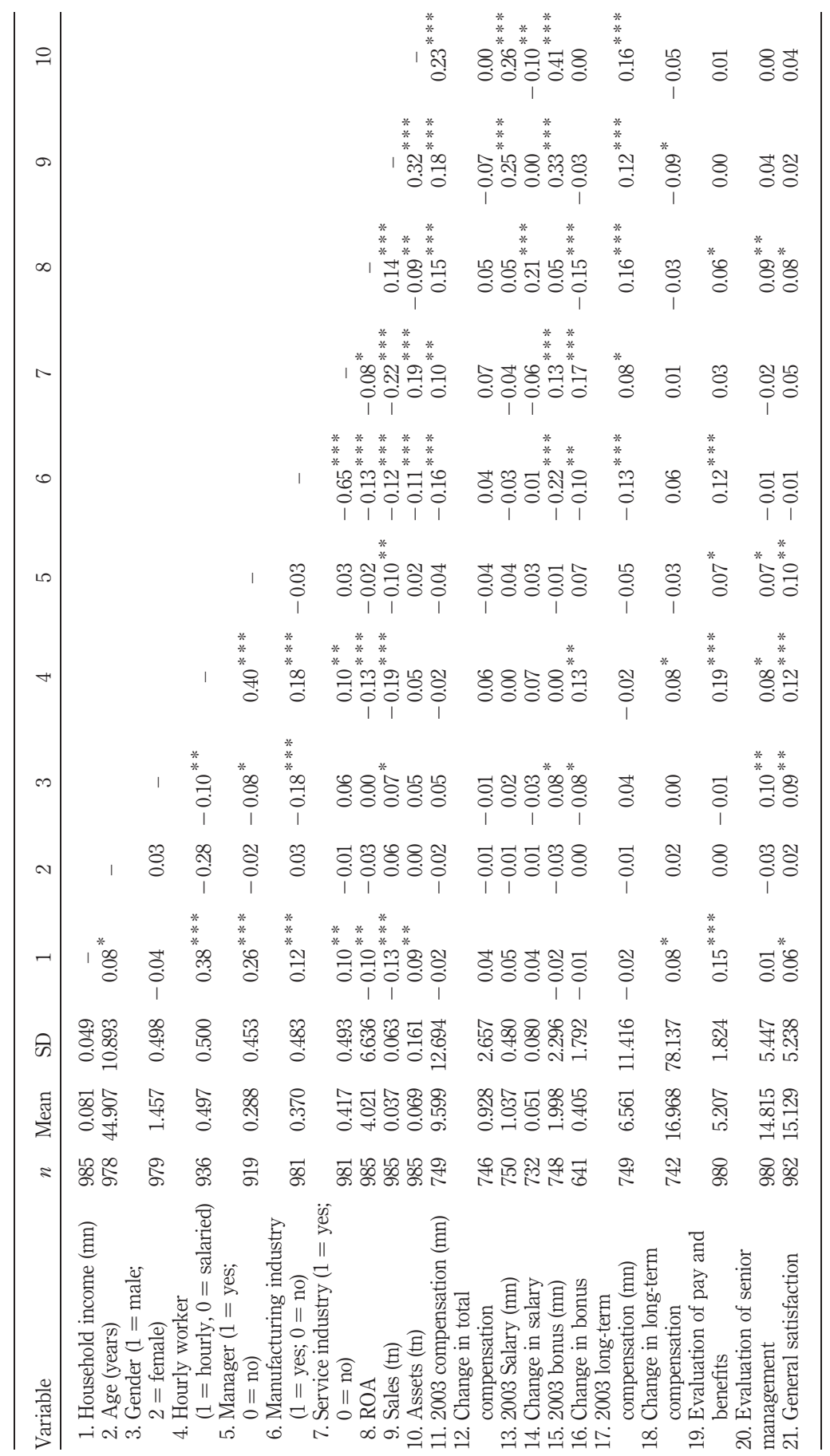




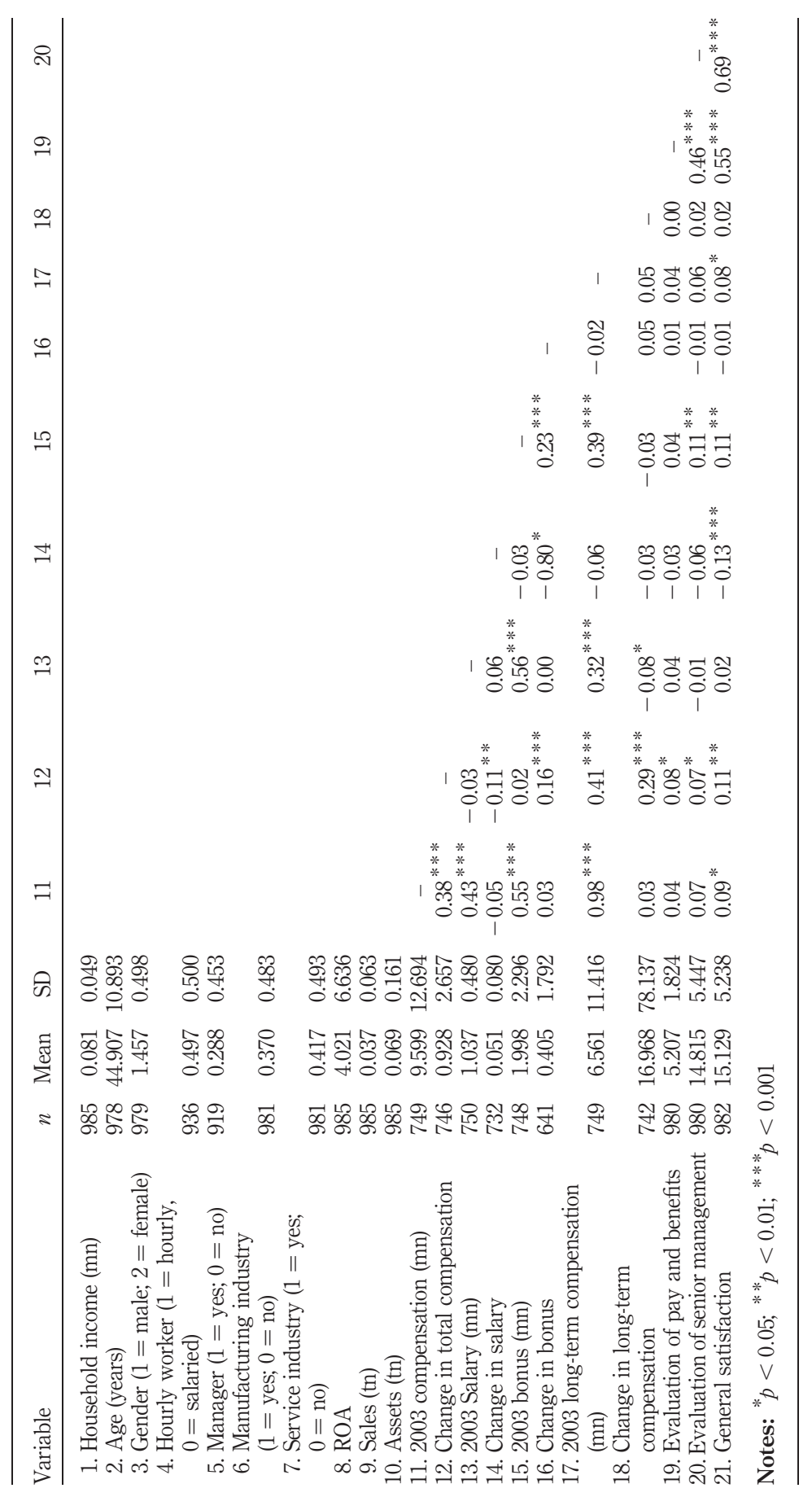

271

Table II. Means, standard deviations and correlations 
PR

41,3

272

that the sizes of the correlations are small (Cohen, 1988) with their absolute values ranging from 0.00 to 0.13 .

Looking at Table III, there is some support for $H 2$ (the efficiency hypothesis), that total CEO compensation will be positively related to employee attitudes, but no support for $H 1$ (the rent extraction hypothesis), that there will be a negative relationship. $H 2$ is supported as the regression coefficients for total compensation change are positive and significant for evaluation of senior management $(b=0.21 ; p<0.001)$ and general satisfaction $(b=0.24 ; p<0.01)$. However, the regression coefficient is not significant in the evaluation of pay and benefits equation. In addition, the regression coefficients for total compensation level are not significant for any of the attitudes at the $p<0.05$ level.

H3, which suggests a negative relationship for components of compensation that are not dependent upon performance, receives some support for CEO salary (Table IV). Specifically, the regression coefficients are negative and significant for change in salary as it relates to both evaluation of senior management $(b=-8.49 ; p<0.01)$ and general satisfaction $(b=-10.62 ; p<0.001)$. However, there are no significant relationships between employee attitudes and level of salary or for change in salary as it relates to evaluation of pay and benefits at the $p<0.05$ level.

$H 4$, which suggests a positive relationship for components of compensation that are dependent upon performance, receives limited support. The coefficient for annual bonus and general satisfaction $(b=0.0002 ; p<0.05)$ is positive and significant (Table V). However, there are no significant relationships between employee attitudes and long-term compensation (Table VI), change in annual bonus (Table V), or for CEO annual bonus (Table V) and evaluation of pay and benefits or evaluation of senior management at the $p<0.05$ level.

\section{Discussion}

So, is there any fire? If there are changes in salary, possibly. Significant, negative relationships were found between percentage change in CEO salary and employee attitudes. Accordingly, when CEO salaries go up sharply, employee attitudes may decline. However, for overall compensation and other components of compensation, the relationships found with employee attitudes were positive with higher CEO compensation related to higher levels of employee attitudes.

This pattern is consistent with the idea that the relationship between CEO compensation and employee attitudes depends upon the attributions that employees make. Employees may view changes in salary negatively because salary is not sensitive to company performance, and thus this component better corresponds to the rent extraction view of CEO compensation. In contrast, the other components and overall measures of compensation are largely performance dependent (Frydman and Jenter, 2010), and this better corresponds to the view that CEO compensation is efficient and implies a positive relationship between compensation and employee attitudes.

However, we cannot rule out alternate explanations. For example, employee attitudes can only be affected by CEO compensation if employees know and understand the information. Of the components, salary is the most straightforward and most similar to what lower-level employees receive. It may be that employees would react negatively to other components of compensation and overall compensation if these components were easier to access and understand. 


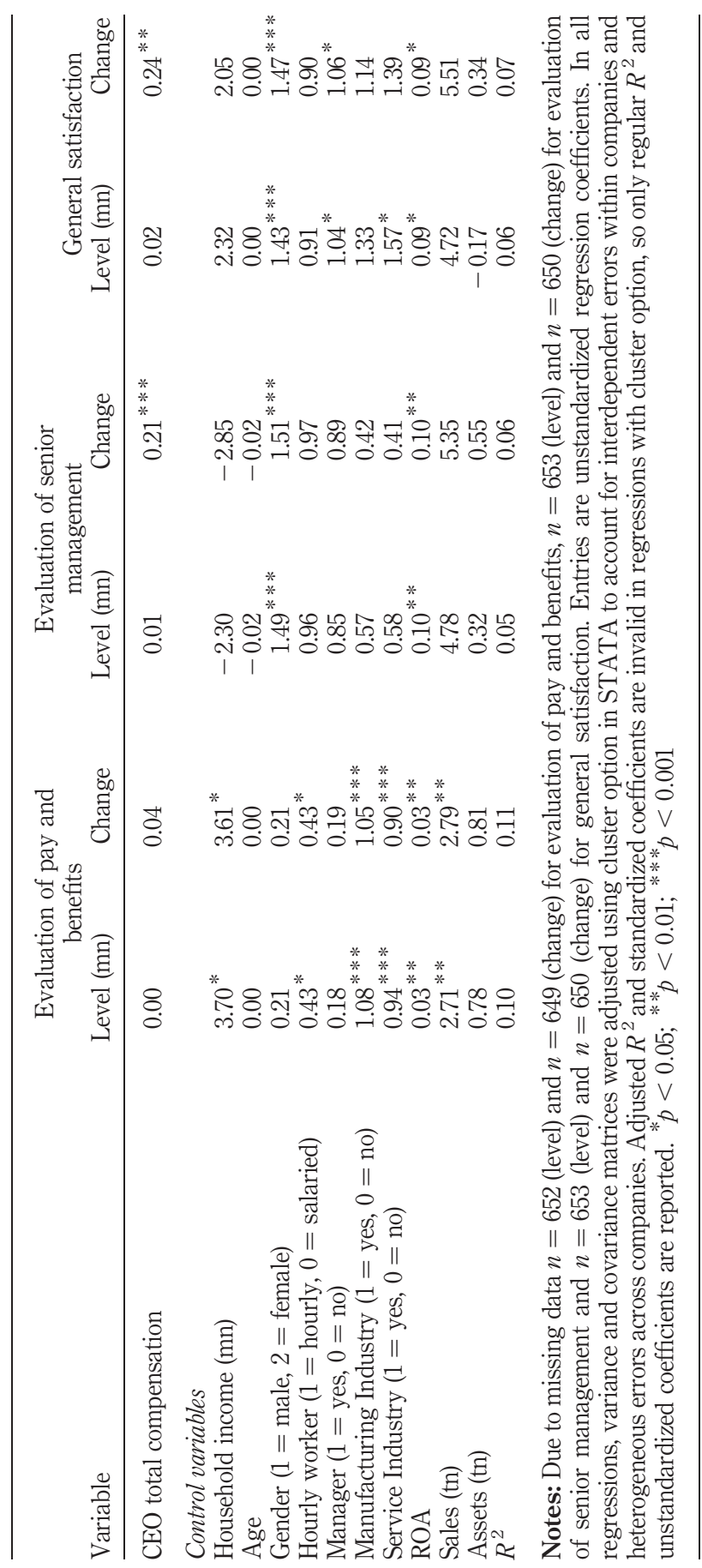

\section{Executive compensation}

273

Table III. Results for CEO total compensation 
PR

41,3

274

Table IV.

Results for CEO salary

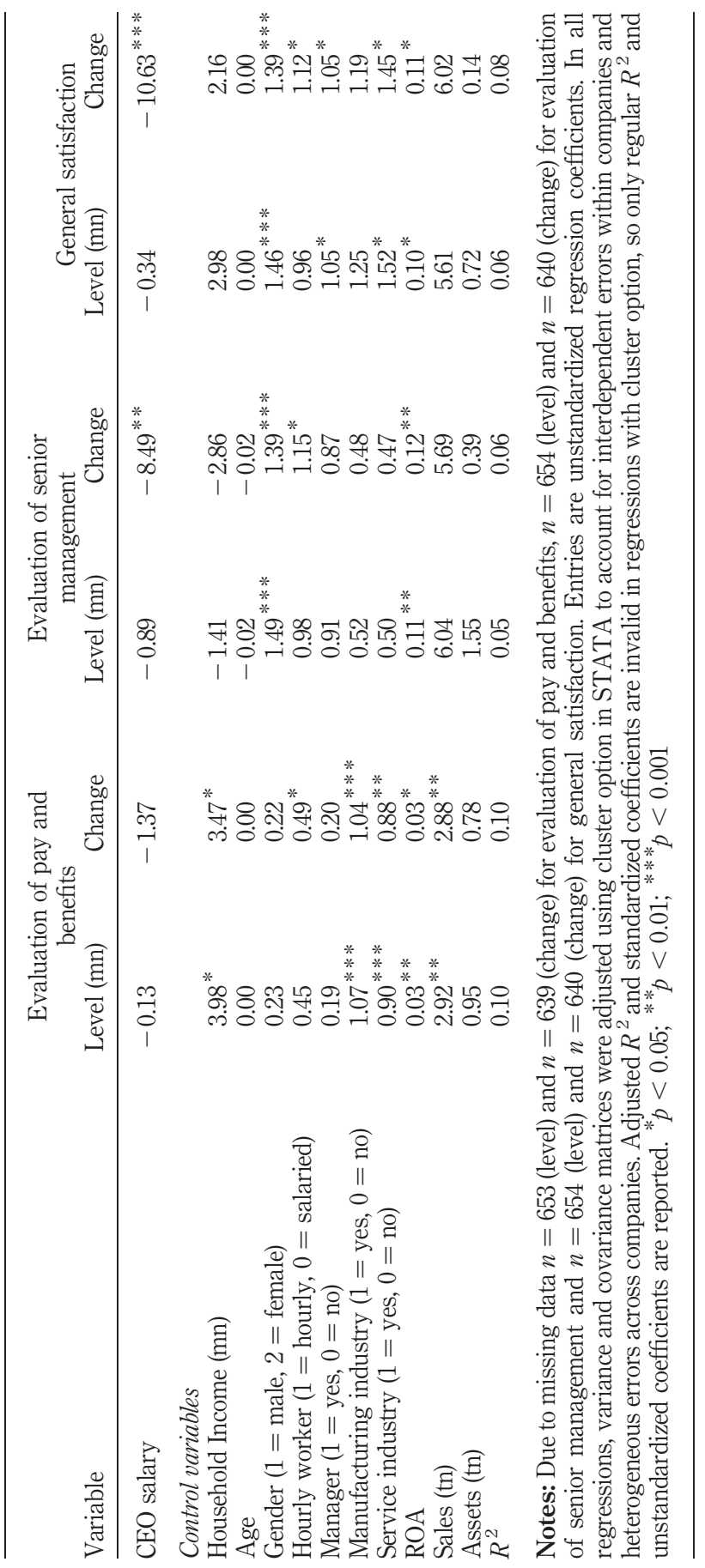




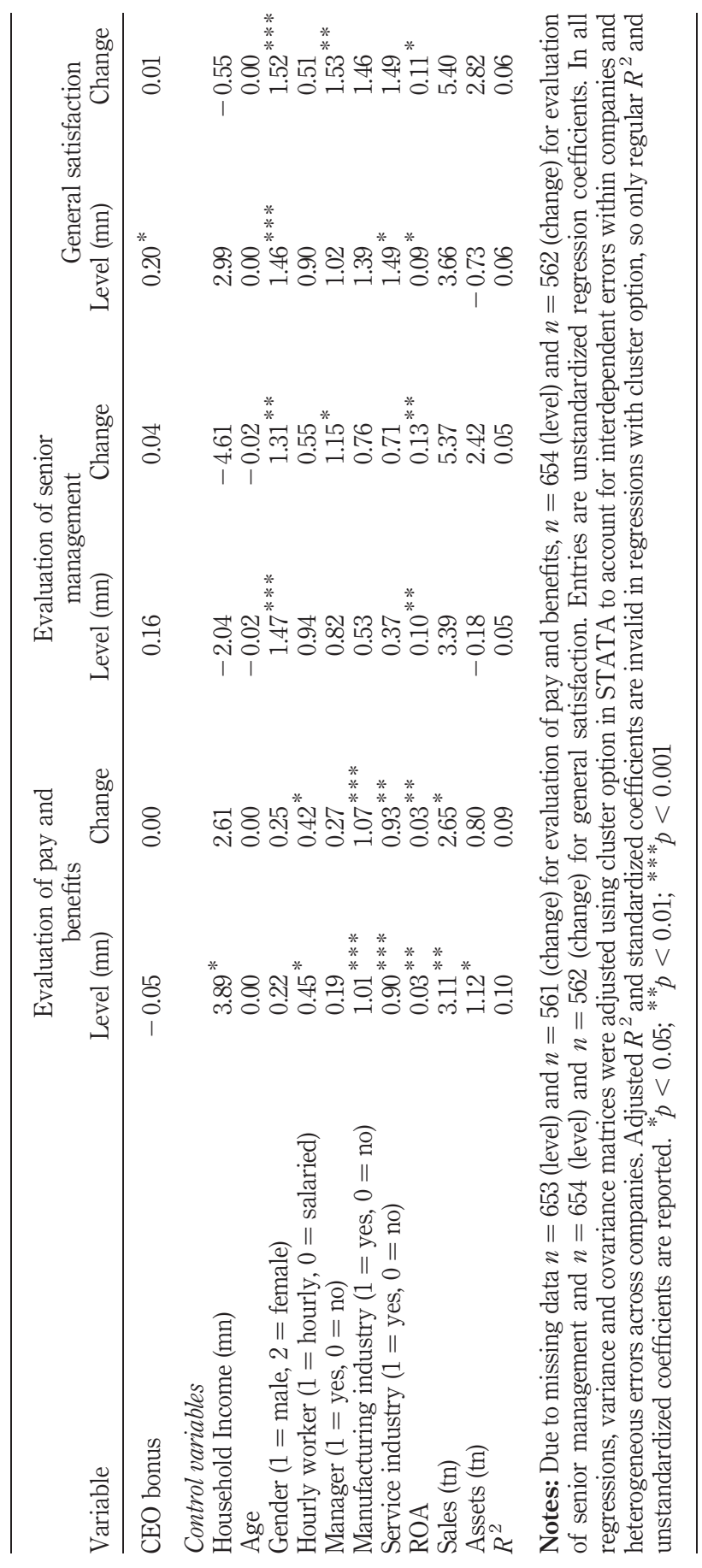

\section{Executive compensation}

275

Table V. Results for CEO bonus 
PR

41,3

276

Table VI.

Results for CEO

long-term compensation

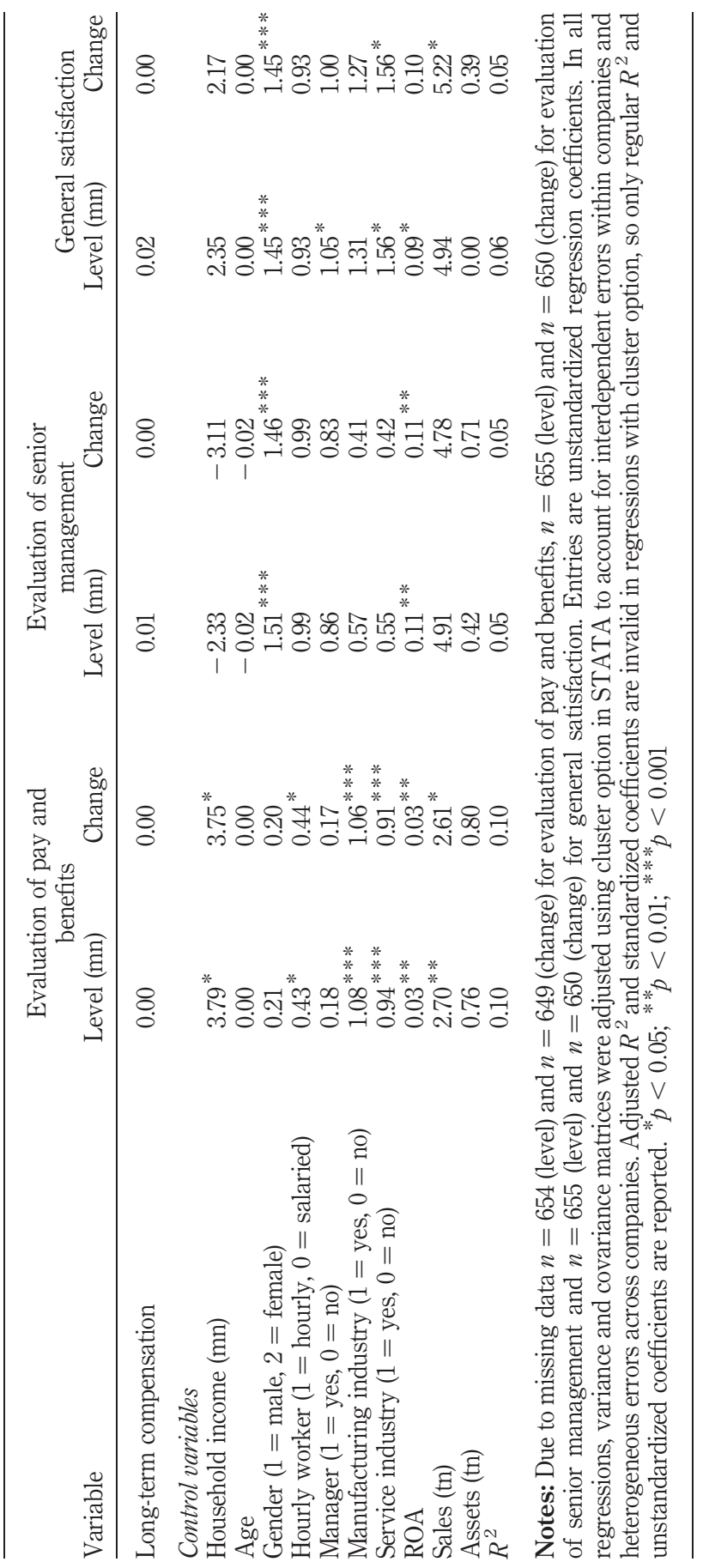


Interestingly, the negative effect sizes for CEO salary change and evaluation of senior management and general satisfaction were 40 times larger than the positive effect sizes for CEO total compensation change and evaluation of senior management and general satisfaction, and nearly twice as large as the positive effect size for CEO bonus level and general satisfaction. Similar to other research, the negative effects outweigh the positive ones (for a review, see Baumeister et al., 2001).

However, while the negative effect sizes were much greater than the positive ones, they were still quite small. A one standard deviation increase in CEO salary change was related to only a 13-17 percent of a standard deviation decrease in employee attitudes. For example, a one standard deviation increase in CEO salary change (+8 percent) was related to a 0.85 point decrease in general satisfaction, which is 17 percent of a standard deviation.

Our findings present one possible explanation of what the popular press has pondered - why there has been no worker revolt over CEO compensation (Krohe, 2005). While employees may react quite negatively to increases in salary, salary is not the component of CEO compensation that has grown rapidly. In fact, between 1992 and 2008 median CEO salaries increased in real dollars only 12.5 percent (Frydman and Jenter, 2010), which is equivalent to 0.7 percent per year. In addition, even when salaries go up, the effect is quite small. This could be because most employees do not know what their CEOs earn, other determinants of employee attitudes are more important, because they do not believe they can do anything about it, or because the effect fades over time.

So, what does this mean for individuals who are involved in setting CEO compensation? From an employee perspective changes in performance-based components of pay are better than changes in salary. This fits with the trend toward incentive-based pay, which is intended to align CEO outcomes with shareholder interests (Edmans and Gabaix, 2009). In addition, if there is going to be a substantial increase in salary, a communication plan should be developed which tries to enhance employees' feelings of procedural justice, including the rationale for the level of compensation and the process that was used to set it, in order to mitigate potentially negative effects on employee attitudes.

Clearly, there are many limitations of this study. First, we are unable to show a causal relationship as there may be variables omitted that explain the relationships. Second, the data is not representative of workers at all companies across all macro-economic conditions. The executive compensation database used to collect CEO compensation figures is skewed toward larger companies, so workers at smaller companies are under-represented, and in 2004 the US economy was growing rapidly, potentially reducing the focus on CEO pay. Third, the equations explain only a small amount of the variance. Fourth, this is not a test of equity theory, because measures of inputs employee output. Finally, the attitudinal measures are single source and not standard measures.

This field is ripe for additional research. First, it would be interesting to understand how much information employees have about CEO compensation. In other words, in terms of CEO compensation how many and which employees know, and what do they know? Second, it would be interesting to find out what mechanisms might be responsible for the relationships that were found. Are attributions important or are organizations that increase CEO salaries less pleasant places to work? 
PR

41,3

278

So, there is a lot of smoke in the press, but not much fire among workers. Only changes in CEO salary were negatively related to employee attitudes, while the other relationships that were found were positive. In addition, all of the relationships that were found were small in terms of effect size. This helps explain why employees have not reacted, except in extreme situations, to increases in CEO compensation even though these increases may appear to be "shameful" (Stolberg et al., 2009) and "extraordinary" (Andersson and Bateman, 1997) to outsiders.

\section{Notes}

1. Many firm characteristics have been studied including firm size and profitability (Tosi et al., 2000), risk (see Miller et al., 2002), acquisitions (Wright et al., 2002), innovation (Balkin et al., 2000), and competitive activity (Offstein and Gnyawali, 2005). CEO characteristics and activities have been studied less frequently (see Grossman and Cannella, 2006; Tosi et al., 2004), and a few studies have examined governance issues (see Cho and Shen, 2007; David et al., 1998; O'Reilly and Main, 2007).

2. For executive compensation to affect employees' attitudes, employees must have some knowledge concerning what their executives make, they must react to the relative level of compensation observed. While little empirical work has examined whether employees know what their executives make, there are numerous sources of this information. SEC filings contain compensation information for CEOs. In addition, there are many secondary sources, including union websites, the media and co-workers.

3. The dollar value of options exercised was chosen over the value of options granted during that year for two reasons. First, the dollar value of options exercised is easier for employees to understand because it is the actual amount of money the CEO received when the options were exercised. In contrast, the dollar value of granted options is a theoretical amount of money that is determined using a complex option-pricing model (i.e. Black-Scholes). Second, it is more accessible to employees, especially in 2004 when three of the major business periodicals - i.e. Business Week, Forbes and the Wall Street Journal - reported executive compensation including the dollar value of exercised options (Anderson et al., 2005).

\section{References}

Adams, J.S. (1963), “Towards an understanding of inequity”, Journal of Abnormal \& Social Psychology, Vol. 67, pp. 422-36.

Adams, J.S. (1965), "Inequity in social exchange", in Berkowitz, L. (Ed.), Advances in Experimental Social Psychology, Vol. 2, Academic Press, New York, NY, pp. 267-99.

Agarwal, N.C. (1981), "Determinants of executive compensation", Industrial Relations, Vol. 20, pp. 36-46.

Anderson, S., Cavanagh, J., Klinger, S. and Stanton, L. (2005), “Executive excess 2005”, available at: www.faireconomy.org/press/2005/EE2005.pdf (accessed January 9, 2007).

Andersson, L.M. and Bateman, T.S. (1997), "Cynicism in the workplace: some causes and effects", Journal of Organizational Behavior, Vol. 1, pp. 449-69.

Associated Press (2005), "Shareholder wants Exxon Mobil board to consider CEO's pay", Associated Press, December 15, available at: http://academic.lexisnexis.com/ (accessed February 16, 2006).

Balkin, D.B., Markman, G.D. and Gomez-Mejia, L. (2000), "Is CEO pay in high-technology firms related to innovation?", Academy of Management Journal, Vol. 43, pp. 1118-29. 
Baumeister, R.F., Bratslavsky, E., Finkenauer, C. and Vohs, K.D. (2001), "Bad is stronger than good”, Review of General Psychology, Vol. 5, pp. 323-70.

Bebchuk, L.A. and Fried, J. (2004), Pay without Performance: The Unfulfilled Promise of Executive Compensation, Harvard University Press, Cambridge, MA.

Bebchuk, L.A. and Grinstein, Y. (2005), "Firm expansion and CEO pay", NBER Working Papers, National Bureau of Economic Research, Cambridge, MA.

Bernaards, C.A. and Sijtsma, K. (2000), "Influence of imputation and EM methods on factor analysis when item nonresponse in questionnaire data is nonignorable", Multivariate Behavioral Research, Vol. 3, pp. 321-64.

Bertrand, M. and Mullainathan, S. (2001), "Are CEOs rewarded for luck? The ones without principles are”, The Quarterly Journal of Economics, Vol. 116, pp. 901-32.

Clark, A.E. and Senik, C. (2009), "Who compares to whom? The anatomy of income comparisons in Europe”, IZA Discussion Papers 4414, Institute for the Study of Labor, Bonn.

Cho, T.S. and Shen, W. (2007), "Changes in executive compensation following an environmental shift: the role of top management team turnover", Strategic Management Journal, Vol. 28, pp. 747-54.

Cohen, J. (1988), Statistical Power Analysis for the Behavioral Sciences, Lawrence Erlbaum Associates, Hillsdale, NJ.

Cohen-Charash, Y. and Spector, P.E. (2001), "The role of justice in organizations: a meta-analysis", Organizational Behavior and Human Decision Processes, pp. 278-321.

Colquitt, J.A., Conlon, D.E., Wesson, M.J., Porter, C.O. and Ng, K.Y. (2001), "Justice at the millennium: a meta-analytic review of 25 years of organizational justice research", Journal of Applied Psychology, Vol. 86, pp. 425-45.

Crosby, F. (1979), "Relative deprivation revisited: a response to Miller, Bolee, and Halligan", American Political Science Review, Vol. 73, pp. 103-12.

Crosby, F. (1984), "Relative deprivation in organizational settings", in Staw, B. and Cummings, L. (Eds), Research in Organizational Behavior, Vol. 6, pp. 51-93.

David, P., Kochhar, R. and Levitas, E. (1998), "The effect of institutional investors on the level and mix of CEO compensation", Academy of Management Journal, Vol. 41, pp. 200-8.

Dekker, I., Barling, J. and Kelloway, E.K. (1996), "Work force size and multifaceted job satisfaction: a cross-national study", Journal of Social Psychology, Vol. 136, pp. 201-8.

Devers, C.E., Cannella, A.A. Jr, Reilly, G.P. and Yoder, M.E. (2007), "Executive compensation: a multidisciplinary review of recent developments", Journal of Management, Vol. 33, pp. 1016-72.

Dittrich, J.E. and Carrell, M.R. (1979), "Organizational equity perceptions, employee job satisfaction, and departmental absence and turnover rates", Organizational Behavior and Human Performance, Vol. 24, pp. 29-40.

Edmans, A. and Gabaix, X. (2009), "Is CEO pay really inefficient? A survey of new optimal contracting theories", European Financial Management, Vol. 15, pp. 486-96.

Festinger, L. (1954), “A theory of social comparison processes”, Human Relations, Vol. 7, pp. 117-40.

Frydman, C. and Jenter, D. (2010), “CEO compensation”, Working Paper No. 77, Rock Center for Corporate Governance, Stanford University, Stanford, CA.

Gabaix, X. and Landier, A. (2008), "Why has CEO pay increased so much?", The Quarterly Journal of Economics, Vol. 123, pp. 49-100. 
PR

41,3

280

Garvey, G.T. and Milbourn, T.T. (2006), "Asymmetric benchmarking in compensation: executives are rewarded for good luck but not penalized for bad”, Journal of Financial Economics, Vol. 82, pp. 197-225.

Glomb, T.M. and Liao, H. (2003), "Interpersonal aggression in work groups: social influence, reciprocal, and individual effects", Academy of Management Journal, Vol. 46, pp. 486-96.

Glomb, T.M. and Welsh, E.T. (2005), "Can opposites attract? Personality heterogeneity in supervisor-subordinate dyads as a predictor of subordinate outcomes", Journal of Applied Psychology, Vol. 90, pp. 749-57.

Goodman, P.S. (1974), "An examination of referents used in the evaluation of pay", Organizational Behavior and Human Performance, Vol. 12, pp. 170-95.

Goodman, P.S. (1977), "Social comparison processes in organizations", in Staw, B.M. and Salancik, G.R. (Eds), New Directions in Organizational Behavior, St Clair Press, Chicago, IL, pp. 97-132.

Gomez-Mejia, L.R. and Wiseman, R.M. (1997), "Reframing executive compensation: an assessment and outlook", Journal of Management, Vol. 23, pp. 291-374.

Greenberg, J. (1990), "Employee theft as a reaction to underpayment inequity: the hidden cost of pay cuts", Journal of Applied Psychology, Vol. 75, pp. 561-8.

Grossman, W. and Cannella, A.A. Jr (2006), "impact of strategic persistence on executive compensation”, Journal of Management, Vol. 32, pp. 257-78.

Hall, B.J. and Liebman, J.B. (1998), “Are CEOs really paid like bureaucrats?”, The Quarterly Journal of Economics, Vol. 113, pp. 653-91.

Harter, J.K., Schmidt, F.L. and Hayes, T.L. (2002), "Business-unit-level relationship between employee satisfaction, employee engagement, and business outcomes: a meta-analysis", Journal of Applied Psychology, Vol. 87, pp. 268-79.

Humphrey, S.E., Nahrgang, J.D. and Morgeson, F.P. (2007), "Integrating motivational, social, and contextual work design features: a meta-analytic summary and theoretical extension of the work design literature", Journal of Applied Psychology, Vol. 92, pp. 1332-56.

Kaplan, S.N. (2008), “Are US CEOs overpaid?”, The Academy of Management Perspectives, Vol. 22, pp. 5-20.

Kidder, D.L. and Buchholtz, A.K. (2002), "Can excess bring success? CEO compensation and the psychological contract”, Human Resource Management Review, Vol. 12, pp. 599-617.

Krohe, J. Jr (2005), "The revolution that never was”, Across the Board, Vol. 42 No. 5, pp. 28-35.

Kulik, C.T. and Ambrose, M.L. (1992), "Personal and situational determinants of referent choice", Academy of Management Review, Vol. 17, pp. 212-37.

Lie, E. (2005), "On the timing of CEO stock option awards", Management Science, Vol. 51, pp. 801-12.

MacDermid, S.M., Hertzog, J.L., Kensinger, K.B. and Zipp, J.F. (2001), "The role of organizational size and industry in job quality and work-family relationships", Journal of Family and Economic Issues, Vol. 22, pp. 191-216.

Maremont, M. (2005), "Latest twist in corporate pay: tax-free income for executives", Wall Street Journal, Vol. 246 No. 136, December 22, pp. A1-A11.

Martin, J. (1981), "Relative deprivation: a theory of distributive injustice for an era of shrinking resources", in Cummings, L. and Staw, B. (Eds), Research in Organizational Behavior, Vol. 3, JAI Press, Greenwich, CT, pp. 53-107. 
Mettee, D.R. and Smith, G. (1977), "Social comparison and interpersonal attraction: the case for dissimilarity", in Suls, J.M. and Miller, R.L. (Eds), Social Comparison Processes: Theoretical and Empirical Perspectives, Hemisphere, Washington, DC, pp. 69-101.

Miller, J.S., Wiseman, R.M. and Gomez-Mejia, L.R. (2002), "The fit between CEO compensation design and firm risk", Academy of Management Journal, Vol. 45, pp. 745-56.

Murphy, K.J. (1999), "Executive compensation", in Ashenfelter, O. and Card, D. (Eds), Handbook of Labor Economics, Vol. 3b, pp. 2485-563.

Nguyen, B.D. and Nielsen, K.M. (2010), "What death can tell: are executives paid for their contribution to firm value?", available at: http://ssrn.com/abstract=1572216

Nguyen, K. (2006), “Tentative deal in Denver transit strike”, Star Tribune, April 6, available at: www.startribune.com (accessed April 7, 2006).

Offstein, E.H. and Gnyawali, D.R. (2005), "Firm competitive behavior as a determinant of CEO pay: empirical evidence from the US pharmaceutical industry", Journal of Managerial Psychology, Vol. 20, pp. 335-54.

Oldham, G.R., Kulik, C.T., Ambrose, M.L., Stepina, L.P. and Brand, J.F. (1986), "Relations between job facet comparisons and employee reactions", Organizational Behavior and Human Decision Processes, Vol. 38, pp. 28-47.

O'Reilly, C.A. III and Main, B.G. (2007), "It's more than simple economics", Organizational Dynamics, Vol. 36, pp. 1-12.

Pritchard, R.D., Dunnette, M.D. and Jorgenson, D.O. (1972), "Effects of perceptions of equity and inequity on worker performance and satisfaction”, Journal of Applied Psychology, Vol. 56, pp. 75-94.

Reckman, R.F. and Goethals, G.R. (1973), "Deviancy and group-orientation as determinants of group composition preferences", Sociometry, Vol. 36, pp. 419-23.

Rogers, W.H. (1993), "sg17: regression standard errors in clustered samples", Stata Technical Bulletin, Vol. 13, pp. 19-23.

Rosen, S. (1986), "Prizes and incentives in elimination tournaments", American Economic Review, Vol. 76, pp. 701-16.

Runciman, W.G. (1966), Relative Deprivation and Social Justice, Routledge and Kegan Paul, London.

Scandura, T.A. and Williams, E.A. (2004), "Mentoring and transformational leadership: the role of supervisory career mentoring”, Journal of Vocational Behavior, Vol. 65, pp. 448-68.

Schneider, B., Hanges, P.J., Smith, D.B. and Salvaggio, A.N. (2003), "Which comes first: employee attitudes or organizational financial and market performance?", Journal of Applied Psychology, Vol. 88, pp. 836-51.

Soldz (2008), "Alternative models for multilevel psychotherapy data", available at: www. soldzresearch.com/papers/AlternativeModelsForMultilevelPsychotherapyData_Notes.pdf (accessed August 26, 2008).

Stolberg, S.G., Labaton, S. and Harwood, J. (2009), "Banker bonuses are 'shameful' - Obama”, New York Times, January 30, available at: http://academic.lexisnexis.com/ (accessed April 6, 2009).

Telly, C.S., French, W.L. and Scott, W.G. (1971), "The relationship of inequity to turnover among hourly workers", Administrative Science Quarterly, Vol. 16, pp. 164-72.

Tervio, M. (2008), "The difference that CEOs make: an assignment model approach", American Economic Review, Vol. 98, pp. 642-68.

\section{Executive compensation}

281 
PR

41,3

282

Tosi, H.L., Werner, S., Katz, J. and Gomez-Mejia, L.R. (2000), "How much does performance matter? A meta-analysis of CEO pay studies", Journal of Management, Vol. 26, pp. 301-39.

Tosi, H.L., Misangyi, V.F., Fanelli, A., Waldman, D.A. and Yammarino, F.J. (2004), "CEO charisma, compensation, and firm performance”, Leadership Quarterly, Vol. 15, pp. 405-20.

Wade, J.B., O'Reilly, C.A. III and Pollock, T.G. (2006), "Overpaid CEOs and underpaid managers: fairness and executive compensation”, Organization Science, Vol. 17, pp. 527-44.

Wright, P., Kroll, M. and Elenkov, D. (2002), "Acquisition returns, increase in firm size, and chief executive officer compensation: the moderating role of monitoring", Academy of Management Journal, Vol. 45, pp. 599-608.

Yermack, D. (1997), "Good timing: CEO stock option awards and company news announcements", The Journal of Finance, Vol. 52, pp. 449-76.

Zellner, W. (2003), "What was Don Carty thinking?”, Business Week, Vol. 32, May.

Zipp, J.R. (1991), "The quality of jobs in small business”, Economic Development Quarterly, Vol. 5, p. 9.

\section{About the authors}

Elizabeth T. Welsh is an Assistant Professor at the University of St Thomas' Opus College of Business in St Paul, Minnesota. In addition to a $\mathrm{PhD}$ in Human Resources and Industrial Relations from the Carlson School of Management at the University of Minnesota, she has an MBA and a Master of Computer Science from UCLA. Her research spans both the human resources and organizational behavior fields, and she has published articles in journals dedicated to these fields. Elizabeth T. Welsh is the corresponding author and can be contacted at: wels2749@stthomas.edu

Deshani B. Ganegoda is a fourth-year PhD Student in the Department of Management at the University of Central Florida. She earned her Bachelor of Business degree and Honors degree (First Class) in Management at Monash University, Australia. Her current research interests include organizational justice, morality, ethics, organizational change and emotions.

Richard D. Arvey is the Head of the Department of Management and Organization, National University of Singapore. He conducts research on human resource practices, organizational behavior and leadership, and the role of genetics in organizational behavior. He received his $\mathrm{PhD}$ from the University of Minnesota and has taught and conducted research at the Universities of Tennessee, Houston, California at Berkeley, and Minnesota.

Dr Jack W. Wiley is founder and Executive Director of the Kenexa High Performance Institute. His research links employee survey results to measures of customer satisfaction and business performance using the WorkTrends ${ }^{\mathrm{TM}}$ survey, which he launched over 25 years ago. He is the author of numerous research papers, articles, book chapters and books including: RESPECT: Delivering Results by Giving Employees What They Really Want (Jossey-Bass) and Strategic Employee Surveys: Evidence-based Guidelines for Driving Organizational Success (Jossey-Bass).

John W. Budd is a Professor of Work and Organizations in the University of Minnesota's Carlson School of Management. He is the author of Employment with a Human Face: Balancing Efficiency, Equity, and Voice (Cornell University Press), Labor Relations: Striking a Balance (McGraw-Hill/Irwin), Invisible Hands, Invisible Objectives: Bringing Workplace Law and Public Policy into Focus (with Stephen Befort, Stanford University Press), The Thought of Work (Cornell University Press), and numerous journal articles.

To purchase reprints of this article please e-mail: reprints@emeraldinsight.com Or visit our web site for further details: www.emeraldinsight.com/reprints 
Reproduced with permission of the copyright owner. Further reproduction prohibited without permission. 